\title{
Acute and Long-Term Outcome of Directional Coronary Atherectomy for Stable and Unstable Angina
}

\author{
Victor A. W. M. Umans, MD, Pim J. de Feyter, MD, Jaap W. Deckers, MD, \\ Donald MacLeod, MD, Marcel van den Brand, MD, Peter de Jaegere, MD, \\ and Patrick W. Serruys, MD
}

The clinical efficacy and safety of directional coronary atherectomy for the treatment of stable and unstable angina were assessed in 82 patients with stable and 68 patients with unstable angina. Therefore, clinical and angiographic follow-up was obtained in a prospectively collected consecutive series of 150 atherectomy procedures. Restenosis was assessed clinically and by quantitative angiography. The overall clinical success rate of atherectomy for patients with unstable and stable angina was $88 \%$ and $91 \%$, respectively. No significant differences were found for inhospital event rates between the unstable and stable angina groups: death (1.5\% vs $0 \%$ ), myocardial infarction ( $10 \%$ vs $6 \%$ ), and emergency bypass operation ( $3 \%$ vs $2 \%$ ). These clinical events were related to the occurrence of abrupt occlusions $(8.8 \%$ in patients with stable and $6.1 \%$ in those with unstable angina; $p=N S$ ). Clinical follow-up was achieved in $100 \%$ of the patients with stable and unstable angina at a mean interval of 923 and 903 days, respectively. Two-year survival rates were $96 \%$ and $97 \%$ in the populations with unstable and stable angina, respectively. There were no significant differences with respect to bypass surgery and angioplasty, but event-free survival at 2 years was significantly lower in the unstable (54\%) than the stable (69\%) angina group. Quantitative coronary angiography did not detect any difference in luminal renarrowing during the 6-month angiographic follow-up period. Although directional

From the Catheterization Laboratory, Thoraxcenter, University Hospital Dijkzigt, Erasmus Lniversity Rotterdam, the Netherlands. Manuscript received January 18. 1994: revised manuscript received and accepted April 8, 1994.

Address for reprints: Victor A. W. M. Umans, MD, Catheterization Laboratory, Thoraxcenter, Erasmus University Rotterdam. P.O. Box 1738. 3000 DR Rotterdam. the Netherlands. coronary atherectomy can be performed effectively in patients with unstable and stable angina, the long-term clinical outcome was less favorable in the unstable angina group. The overall higher incidence of adverse events in patients with unstable angina occurred despite the excision of unstable plaque material, and may therefore reflect the inherent instability of the syndrome rather than the inability of atherectomy to establish a persistent success.

(Am J Cardiol 1994;74:641-646)

$\mathrm{I}$ ncreasing operator experience has rendered directional coronary atherectomy a safe and successful treatment for patients with symptomatic coronary artery disease. However, the long-term outcome of atherectomy is still limited by unpredictable progression to recurrent stenosis, although it was hypothesized that controlled plaque removal by the atherotome might lead to favorable short- and long-term results. ${ }^{1,2}$ Despite these findings, directional coronary atherectomy may be beneficial in particular patient groups. The management of patients with unstable angina continues to receive much attention, and conventional balloon angioplasty has assumed an important role in the treatment of this condition. However, most reported series demonstrated complication rates in excess of those seen in patients with stable angina undergoing angioplasty. ${ }^{3-5}$ This is thought to be related to the complex nature of unstable lesions where plaque ulceration and mural thrombus appear to be important. ${ }^{6-8}$ Also, it has been suggested that angioplasty in the context of unstable angina is associated with increased restenosis rates ${ }^{9.10}$ although this has not been confirmed by other investigators. ${ }^{3-5,11}$ The potential for atherectomy to improve the outcome of unstable angina has not been determined. We therefore examined whether preprocedural anginal status influenced immediate and late clinical progress in a prospective cohort of 143 patients undergoing 150 directional coronary atherectomy procedures in our institution. 


\begin{tabular}{|c|c|c|}
\hline & Unstable $(n=68)$ & Stable $(\mathrm{n}=82)$ \\
\hline Age (years) & $58 \pm 11$ & $58 \pm 10$ \\
\hline Male gender & $57(84 \%)$ & $66(80 \%)$ \\
\hline \multicolumn{3}{|l|}{$\begin{array}{l}\text { New York Heart Association } \\
\text { functional class }\end{array}$} \\
\hline II & - & $33(40 \%)$ \\
\hline III & - & $49(60 \%)$ \\
\hline IV & $68(100 \%)$ & - \\
\hline Previous infarction & $21(31 \%)$ & $16(20 \%)$ \\
\hline Previous PTCA & $12(18 \%)$ & $17(21 \%)$ \\
\hline Multivessel disease & $10(15 \%)$ & $14(17 \%)$ \\
\hline \multicolumn{3}{|l|}{ Target coronary artery } \\
\hline Left anterior descending & $45(66 \%)$ & $57(70 \%)$ \\
\hline Right coronary artery & $18(26 \%)$ & $15(18 \%)$ \\
\hline Left circumflex & $5(7 \%)$ & $10(12 \%)$ \\
\hline
\end{tabular}

\section{METHODS}

Patient selection: Between September 1989 and January 1993, 143 patients underwent 150 directional coronary atherectomy procedures for stable and unstable angina. Patients were considered candidates for directional atherectomy when coronary angiography revealed a severc, cccentric noncalcified stenosis in the proximal nontortuous part of an epicardial coronary artery with an anticipated reference diameter of $\geq 3.0 \mathrm{~mm}$.

Clinical definitions: Unstable angina was defined as chest pain at rest while hospitalized, and accompanied by electrocardiographic evidence of myocardial ischemia (ST-segment or T-wave changes) despite optimal medication including intravenous nitroglycerin and heparin,

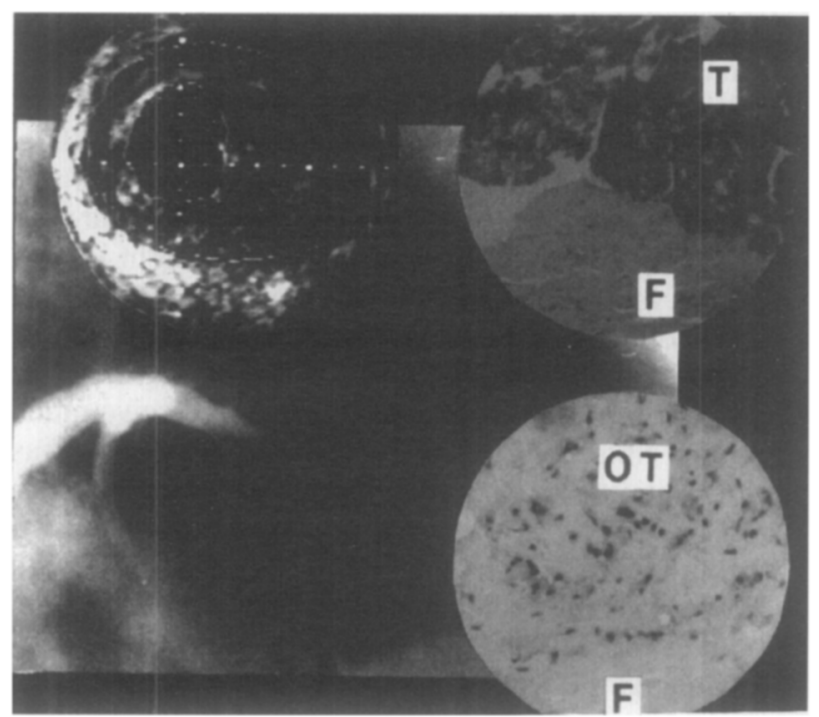

FICURE 1. Coronary angiogram and histologic findings in a patient with unstable angina before atherectomy. Coronary anglography showed an eccentric lesion with smooth borders located in the midportion of the left anterior descending coronary artery. Intracoronary ultrasound imaging revealed an underlying eccentric plaque with heterogeneous echogenicity and without calcific deposits. Histopathologic examination of the retrieved material disclosed areas of thrombotic material (T) with different degrees of organization (OT) in close apposition to moderately cellular fibrotic tissue (F). among others, without evidence of subsequent myocardial necrosis. All other clinical syndromes of ischemic heart disease were defined as stable angina. Recent myocardial infarction was defined as transmural (electrocardiographic $Q$ wave) or nontransmural (no $Q$ wave), when chest pain was associated with a peak creatine kinase elevation greater than twice the upper limit of normal values during the preceding 7 days. Abrupt occlusion was defined as a total occlusion of the coronary artery at any time during or after the atherectomy procedure.

clinical end points: The follow-up of all patients treated with atherectomy was begun at the end of the procedure. The following clinical events were recorded:

DEATH: All deaths were considered cardiac unless they were documented to the contrary.

MYOCARDIAL INFARCTION: The development of new abnormal $Q$ waves on the electrocardiogram or an enzyme change by $>2$ times the upper limit of normal creatinc kinase.

CORONARY ARTERY BYPASS SURGERY: Classified as emergency, in-hospital elective, or during follow-up.

REPEAT ANGIOPLASTY: Any reinsertion of a guiding catheter followed by a new angioplasty.

Directional coronary atherectomy: The procedure was performed as previously described. ${ }^{12-17}$ Briefly, all patients were pretreated with $250 \mathrm{mg}$ of acetylsalicylic acid, 10,000 $\mathrm{U}$ of heparin intravenously and isosorbide dinitrate. Procedural success was defined as a residual diameter stenosis of $<50 \%$ after atherectomy with or without balloon angioplasty. Clinical success was defined as a procedural success without in-hospital adverse clinical events (death, myocardial infarction, bypass surgery).

Quantitative coronary anglography: Quantitative analysis of the coronary segments was performed with the computer-based coronary angiography analysis system, previously described in detail. ${ }^{15-19}$ In essence, boundaries of a selected coronary artery segment are detected automatically from optically magnified and video-digitized regions of interest ( $512 \times 512$ pixels $)$ of a cineframe. The absolute diameter of the stenosis in millimeters is determined using the guiding catheter as a scaling device. Calibration of the catheter in absolute values ( $\mathrm{mm}$ ) is achieved by comparing the mean diameter of the catheter in pixels with the measured size in millimeters.

Statistical analysis: Mean values \pm SD are given for continuous variables. Comparisons of mean values were performed using a 2-tailed paired $t$ test. Categorical variables were compared using chi-square tests with Yates' continuity correction applied where appropriate. A p value $<0.05$ was considered significant.

\section{RESULTS}

Clinical and angiographic demographics: Of the 150 procedures, 82 were performed in patients with stable angina and 68 in patients with unstable angina. Baseline clinical and angiographic characteristics are reported in Table I. Similar baseline characteristics were found among the groups, but patients with unstable angina sustained more infarctions before atherectomy (Figure 1). Most atherectomy procedures were performed in the left anterior descending coronary artery $(70 \%)$, with more 
right coronary artery lesions in the unstable group. Most narrowings were primary stenosis, although $20 \%$ of the patients underwent atherectomy for restenosis after previous angioplasty.

Procedural results: In the group with unstable angi$\mathrm{na}$, stand-alone atherectomy was performed in $64 \mathrm{pa}-$ tients, with clinical success in $62(97 \%)$. In 1 patient, plaque embolization with subsequent side-branch occlusion occurred, and another patient underwent elective bypass surgery after an unsuccessful emergency atherectomy procedure. Adjunctive balloon angioplasty $(n=4)$ was performed for the following angiographic complications: a nose-cone dissection $(\mathbf{n}=2)$, and an abrupt total occlusion $(n=2)$. Balloon dilatation was angiographically successful in all patients; however, 1 of these patients was subsequently referred for emergency coronary artery bypass surgery because of refractory threatening occlusion.

In the group with stable angina, stand-alone atherectomy was performed in 77 patients $(94 \%)$. Adjunctive balloon angioplasty was performed in 5 patients to improve the postatherectomy result. In this group no procedural abrupt occlusions were seen. The procedural success rate for unstable and stable angina was $96 \%$ and $99 \%$, respectively $(\mathrm{p}=\mathrm{NS})$.

In-hospital success and complications: The clinical success rate defined as an angiographic success in absence of death, myocardial infarction, or emergency or elective in-hospital bypass surgery was $88 \%$ (60 of 68 patients) for unstable angina and $91 \%$ (75 of 82 patients) for stable angina ( $\mathrm{p}=\mathrm{NS}$ ).

Major clinical complications developed in 15 patients, usually related to the occurrence of an abrupt occlusion. In all, the incidence of abrupt occlusion was $7.3 \%(8.8 \%$ vs $6.1 \%$ in the unstable and stable groups; $\mathrm{p}=\mathrm{NS}$ ). Procedural occlusions occurred in 4 patients $(5.9 \%)$ with unstable and in 1 patient $(1.2 \%)$ with stable

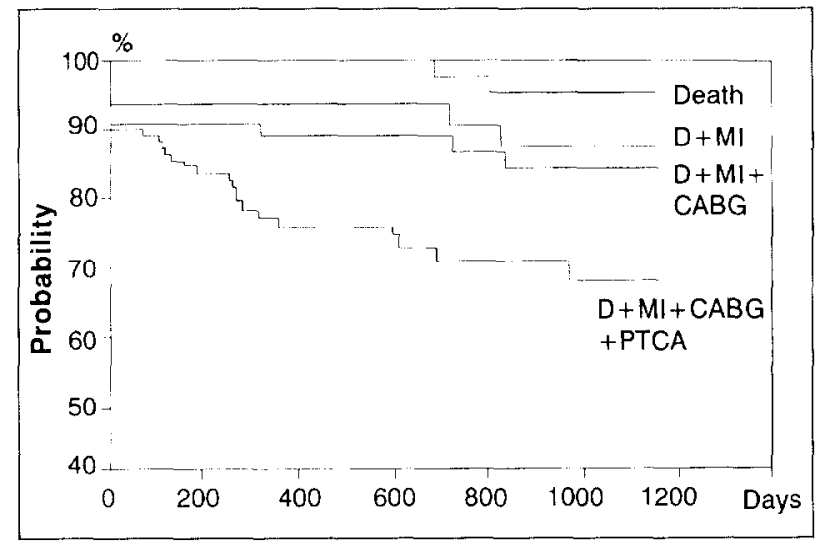

FIGURE 2. Probability of survival and event-free survival after directional coronary atherectomy for stable angina. The Kaplan-Meier estimates of freedom from the following events are shown: death (D); death and myocardial infarction (MI); death, myocardial infarction, and coronary artery bypass grafting (CABG); or death, myocardial infarction, coronary artery bypass grafting, and repeat percutaneous transiuminal coronary angioplasty (PTCA). The 2-year probability of freedom from death was $97 \%$. The 2-year probability of freedom from death, myocardial infarction, coronary artery bypass grafting, and percuta neous transluminal coronary angioplasty was $69 \%$. angina. In the unstable angina group, these were guiding catheter-induced in 2, nose-cone-induced in 1 , or occurred after dilatation of an occluded side branch (n $=1$ ). Three of these were treated by angioplasty or stenting, or both. One patient was subsequently referred for emergency surgery after successful dilatation. One procedural occlusion (guiding catheter-induced) occurred in the stable group. Subacute occlusions occurred in 2 patients $(2.9 \%)$ in the unstable and in 4 patients $(4.8 \%)$ in the stable group $(\mathrm{p}=\mathrm{NS})$. All patients were immediately transferred back to the catheterization suite for subsequent successful balloon angioplasty, and all except 1 had a myocardial infarction. Therefore, an occlusion at the site of atherectomy occurred in $4.4 \%$ of the unstable and $4.8 \%$ of the stable procedures $(\mathrm{p}=\mathrm{NS})$.

In-hospital death occurred in 1 patient with unstable angina 3 days after a successful bailout atherectomy. This patient developed cardiac tamponade secondary to a coronary perforation at the site of atherectomy.

Q-wave myocardial infarction occurred in 7 patients (10\%) with unstable and 5 patients $(6 \%)$ with stable angina $(\mathrm{p}=\mathrm{NS})$. In the unstable angina group, 5 of the 7 infarctions ( $71 \%$ ) were due to a (sub)acute occlusion, 1 patient had an unsuccessful emergency atherectomy after failed thrombolysis in the setting of an acute myocardial infarction, and 1 patient had a plaque embolization that resulted in a side-branch occlusion. Four of the 5 infarctions $(80 \%)$ in the stable angina group occurred in the setting of a subacute occlusion.

Coronary bypass surgery was performed immediately in 2 patients in each group and on an elective basis in 1 patient in each group. All patients who underwent emergency surgery except 1 developed a transmural infarction.

Long-term clinical outcome: Clinical follow-up was achieved in $100 \%$ of patients with stable and unstable angina at a mean follow-up interval of 903 days in the unstable and 923 days in the stable angina group. This

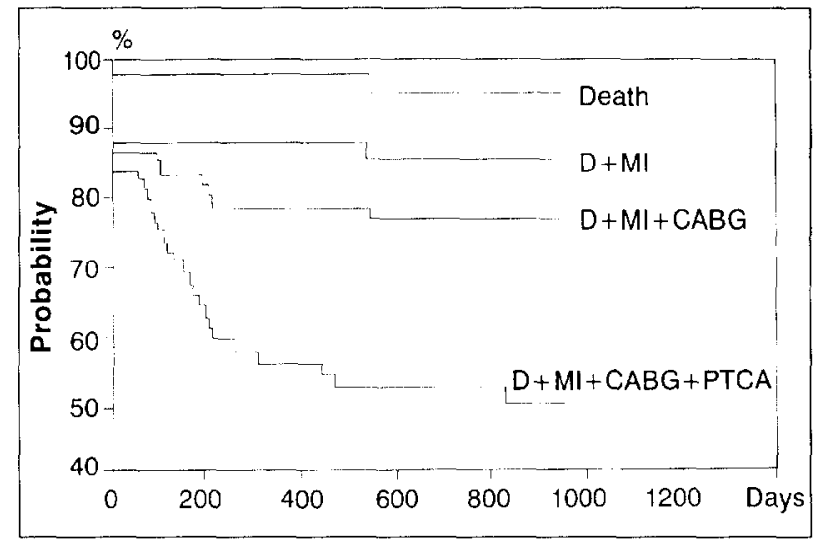

FIGURE 3. Probability of survival and event-free survival after directional coronary atherectomy for unstable angina. The Kaplan-Meier estimates of freedom from the following events are shown: death (D); death and myocardial infarction (MI); death, myocardial infarction, and coronary artery bypass grafting (CABG); death, myocardial infarction, coronary artery bypass grafting, and repeat percutaneous transluminal coronary angioplasty (PTCA). The 2-year probability of freedom from death was $96 \%$. The 2-year probability of freedom from death, myocardial infarction, coronary artery bypass grafting, and percutaneous transluminal coronary angioplasty was $54 \%$. 


\begin{tabular}{|lcc|}
\hline \multicolumn{3}{|l|}{$\begin{array}{l}\text { TABLE II Quantitative Angiographic Analysis of Immediate and } \\
\text { Late Effects of Directional Coronary Atherectomy in Patients with } \\
\text { Unstable and Stable Angina }\end{array}$} \\
\hline \multicolumn{3}{|c|}{ Unstable } \\
\hline \multicolumn{3}{|c|}{ Stable } \\
\hline Reference diameter before (mm) & $3.29 \pm 0.59$ & $3.17 \pm 0.63$ \\
Minimal luminal diameter before (mm) & $1.17 \pm 0.39$ & $1.17 \pm 0.40$ \\
Minimal luminal diameter after (mm) & $2.38 \pm 0.48$ & $2.36 \pm 0.58$ \\
Minimal luminal diameter F-Up (mm) & $1.70 \pm 0.49$ & $1.66 \pm 0.56$ \\
\% Diameter stenosis before & $64 \pm 11$ & $63 \pm 11$ \\
$\%$ Diameter stenosis after & $28 \pm 12$ & $29 \pm 15$ \\
\% Diameter stenosis F-Up & $46 \pm 18$ & $41 \pm 18$ \\
$\%$ Area stenosis before & $85 \pm 9$ & $85 \pm 7$ \\
\% Area stenosis after & $46 \pm 12$ & $47 \pm 17$ \\
\% Area stenosis F-Up & $68 \pm 17$ & $62 \pm 21$ \\
Absolute gain in lumen (mm) & $1.20 \pm 0.52$ & $1.20 \pm 0.57$ \\
Relative gain in lumen & $0.39 \pm 0.22$ & $0.38 \pm 0.21$ \\
Absolute loss in lumen (mm) & $0.68 \pm 0.68$ & $0.74 \pm 0.62$ \\
Relative loss in lumen & $0.23 \pm 0.27$ & $0.25 \pm 0.20$ \\
\hline F-Up = follow-up: before = before atherectomy; after $=$ after artherectomy. \\
\hline
\end{tabular}

analysis involved all patients including those with an unsuccessful atherectomy procedure. Event-free survival was defined as survival in the absence of myocardial infarction, coronary bypass surgery, or repeat transluminal intervention. Figures 2 and 3 show the initial and late freedom from events as assessed by the Kaplan-Meier analysis for the unstable and stable angina groups. Oneand 2-year survival were $98 \%$ and $96 \%$ in the unstable and $100 \%$ and $97 \%$ in the stable angina group, respectively. During follow-up, 1 patient $(1.4 \%)$ from the unstable angina group died suddenly. Four patients $(4.9 \%)$ from the stable angina group died during follow-up: 1 cardiac and 3 noncardiac deaths. No other patients than those who died of cardiac causes had a myocardial infarction. Coronary bypass surgery for recurrent angina was performed in 5 patients with unstable and 2 with stable angina ( $7.5 \%$ vs $2.4 \%$; $\mathrm{p}=\mathrm{NS}$ ). Repeat angioplasty was performed in 12 patients $(17.6 \%)$ with unstable and $15(18.3 \%)$ with stable angina, including 4 patients who had an angioplasty for a lesion other than at the site of the index atherectomy. Thus, at 1 and 2 years, $57 \%$ and $54 \%$ of the patients with unstable angina and $74 \%$ and $69 \%$ of those with stable angina were event free. The difference in event-free survival between the groups was statistically significant $(\mathrm{p}<0.02)$.

Quantitative angiography: Follow-up angiography was performed in $92 \%$ of the unstable and in $90 \%$ of the stable eligible patients. The results of quantitative angiographic assessment of atherectomy for unstable and stable angina are detailed in Table II. No differences in reference diameter and lesion severity (minimal luminal diameter, diameter stenosis, and area stenosis before atherectomy) were observed. After atherectomy there was a significant improvement in minimal luminal diameter, diameter stenosis, and area stenosis in patients with unstable and stable angina $(\mathrm{p}<0.001)$. During follow-up, both groups showed a comparable deterioration in luminal geometry, as reflected by a decrease in minimal luminal diameter and an increase in diameter stenosis and area stenosis. When we used the $50 \%$ diameter stenosis criterion, restenosis occurred in $39 \%$ of unstable and $32 \%$ of the stable lesions $(\mathrm{p}=\mathrm{NS})$. At follow-up, no dif- ference was seen in minimal luminal diameter between both groups after procedures were performed for proximal left anterior descending artery lesions ( $1.68 \pm 0.55$ vs $1.61 \pm 0.64 \mathrm{~mm} ; \mathrm{p}=\mathrm{NS}$ ), and no difference in restenosis rates was observed ( $30 \%$ vs $32 \%$; $p=N S)$.

\section{DIscussion}

The major findings of this study are threefold. First, a similar high acute angiographic and clinical success rate was found for unstable and stable angina. Second, during a 2-year follow-up period, patients initially treated for unstable angina had a significantly lower eventfree survival than those treated for stable angina. Third, quantitative coronary angiography revealed that luminal renarrowing after atherectomy in patients with unstable angina was similar to that for patients with stable angina, and thus patients with unstable angina had no higher incidence of restenosis.

Study design: In singlc and multicenter serics, directional atherectomy has been demonstrated to be a safe and effective alternative to coronary angioplasty in selected patients. ${ }^{1,2,12-17}$ Multivariate analysis has revealed a limited number of lesion and procedural variables, but no clinical characteristics as independent although weak predictors of restenosis. ${ }^{20}$ In particular, anginal status has not been found to correlate with late outcome. Recent angioplasty data, however, suggest that unstable angina is associated with restenosis on univariate analysis, ${ }^{21,22}$ whereas recent-onset angina was retained in the multivariate analysis model as a predictor for angiographic restenosis. ${ }^{21}$ Whether these discrepancies between atherectomy and angioplasty data are due to the different mechanisms of action (debulking vs dilating) or to selection bias or heterogenicity of the (un)stable population has not been determined. We assessed the clinical and angiographic outcome after atherectomy in our strictly defined homogeneous patient population, with objectively documented unstable angina.

Immediate clinical outcome: The association between the clinical anginal syndrome and the occurrence of (sub)acute complications after atherectomy has not been reported to date. The previous angioplasty experience of our group and others resulted in a less favorable clinical course after angioplasty for patients with unstable than stable angina. ${ }^{3}{ }^{5,23}$ The present study concurs with these observations and indicates that atherectomy for unstable angina is related to a higher, although not statistically significant, incidence of (sub)acute occlusion when compared with stable angina $(8.8 \%$ vs $6.1 \% ; \mathrm{p}=$ NS). Although an occlusion rate of $7.3 \%$ is higher than previously reported, ${ }^{12,24}$ this may be due to the higher incidence of unstable angina (45\%) in the present study population. Popma et $\mathrm{al}^{24}$ found an occlusion rate of 4.3\% after directional atherectomy, with a higher incidence in de novo lesions, right coronary artery stenoses, and diffuse lesions. In addition, Ellis et $\mathrm{al}^{25}$ determined other adverse angiographic lesion characteristics that increase the risk of acute complications. The (sub)acute occlusion phenomenon after atherectomy in patients with stable and unstable angina demands adequate bailout strategies, and additional caution is appropriate with regard to the use of the bulky, stiff atherectomy device. 
The introduction of new, lower profile atherectomy devices may further increase procedural success rates, particularly since the initially occurring nose-cone-induced dissections have not been observed since their introduction.

The difference in acute complications between patients with unstable and stable angina (12\% vs $9 \%$, respectively; $p=N S$ ) indicates that the $11 \%$ clinical complication rate in patients who underwent atherectomy in the Coronary Angioplasty Versus Excisional Atherectomy Trial may indeed be related to the clinical syndrome of unstable angina that was present in $66 \%$ of the population. ${ }^{1} \mathrm{~A}$ higher incidence of immediate postatherectomy complications in patients with unstable angina is presumably related to the presence of complex coronary artery lesions. ${ }^{26-28}$ These lesions contain more thrombus as observed at angioscopy ${ }^{28}$ and confirmed by histology, ${ }^{29.30}$ and have more calcium, ${ }^{29}$ which is known to be associated with unsuccessful atherectomy procedures.

Long-term clinical follow-up: Similar to the findings of Fishman et $\mathrm{a}^{31}$ our study explored the effect of unstable angina as the index cardiac syndrome on the longterm outcome after directional atherectomy and indicates that unstable angina was associated with a less favorable long-term clinical follow-up. The majority of the adverse events consisted of revascularizations that occurred earlier in patients with unstable than stable angina. No difference in balloon angioplasty for angiographic restenosis was observed during follow-up in both groups, although a trend toward more coronary artery bypass surgery in the group with unstable angina was found. These results strongly suggest that anginal status at the time of atherectomy had an impact on late clinical outcome. Differences in baseline patient characteristics could not contribute to these dissimilar follow-up results because the 2 patient groups were comparable apart from previous myocardial infarctions. The higher incidence of previous myocardial infarctions may reflect the inherent instability of the unstable coronary syndrome, likewise accounting for the higher incidence of acute and late events in such patients. It would appear that the syndrome of unstable angina is not wholly explained by lesion characteristics because excision of the unstable plaque by atherectomy did not yield a long-term clinical outcome similar to that in patients with stable angina. These findings concur with observations that restenosis after balloon angioplasty for unstable angina is associated with an aggressive pattern of angina. ${ }^{32} \mathrm{~A}$ similar difference in clinical outcome has been reported for balloon angioplasty. ${ }^{32,33}$ Although these results suggest that there is no advantage of atherectomy over balloon angioplasty, a comparison with historical data should not be made because of clinical and angiographic differences between these populations.

Does unstable angina result in more restenosis? The luminal renarrowing process in the unstable angina group was similar to that in the stable angina group. At late angiographic follow-up, the minimal luminal diameter was $1.70 \pm 0.49 \mathrm{~mm}$ in the unstable and $1.66 \pm 0.56$ $\mathrm{mm}$ in the stable angina population. Using the $\geq 50 \%$ diameter stenosis restenosis definition, no statistical difference in restenosis rate was observed at 6-month angiography: $39 \%$ in patients with unstable and $32 \%$ in patients with stable angina. These results are consistent with angioplasty reports, ${ }^{3,5,11,32}$ and confirm our previous observation that clinical parameters are not independent predictors of late residual lumen or late loss after directional atherectomy. ${ }^{20}$ The inconsistency between the long-term clinical and angiographic outcome may be related to the aggressiveness of the anginal pattern in patients with unstable angina, prompting repeat interventions at the time of restenosis. ${ }^{32}$

1. Topol EJ, Leya F. Pinkerton CA. Whitlow PL, Hofling B. Simonton CA. Mas den RR, Serruys PW, Leon MB, Williams DO, King SB, Mark DB, Isner JM Holmes DR, Ellis SG, Lee KL. Keeler GP, Berdan LG. Hinohara T. Califf RM. A comparison of directional atherectomy with coronary angioplasty in patients with coronary artery disease. N Engl J Med 1993:329:221-227.

2. Adelman $A G$, Cohen $M$, Kimball BP, Bonan R, Ricci DR, Wehb JG, Laratne L, Barbeau G. Traboulsi M, Corbett BN, Schwartz L, Logan AG. Canadian Coro nary Atherectomy Trial. A randomized comparison of directional cormary atherectomy and percutaneous transluminal coronary angioplasty for lesions of the proximal left anterior descending artery. $N$ Engl J Med 1993:329:228-234.

3. de Feyter PJ, Serruys PW. van den Brand M, Balakumaran K. Mochtar B. Soward Al., Amold AFR, Hugenholtz PC. Fmergency comnary angioplakiy in retratetory unstable angina. $N$ Engl $J$ Med 1985:313:342-347.

4. de Feyter PJ, Suryapranata H. Serruys PW. Beatt KJ, van Domburg R. vin den Brand $\mathrm{M}$, Tijssen J. Azar A, Hugenholtz PG, Coronary angioplasty for unstabje angina: immediate and late results in 200 consecutive patients with identification of risk factors for unfavorable early and late outcome. I Am Coll Cadiol 1988: 12:324-333.

5. Qungley PJ, Erwin J, Maurer BJ, Walsh MJ, Gearty Gr. Percutaneous Mansluminal coronary angioplasty in unstable angina: comparison with statle angina. $\mathrm{Br}$ Heart J 1986:55:227-230.

6. Falk E. Unstable angina with fatal outcome: dynanic coronary thronl om in lcinting to infarction and/or sudden death. Circulation 1985:71:699-708.

7. Davies MJ. Thomas AC. Plaque fissuring: the cause of acute myocardial intarction, sudden ischemic death and crescendo angina. Br Hedrt 7 1985:53:36,3-373. 8. Ambrose JA. Plaque disruption and the acute coronary syndromes of unstable angina and myocardial infarction: if the substrate is similar, why is the clinical pre sentation different? J Am Coll Cardiol 1992;19:1653-1658

9. Leimgruber PP, Roubin GS. Hollman J, Cotsonis GA, Meier B, Douglas JS, King SB 1II, Gruntrig AR. Restenosis after successful coronary angioplasty in patients with single vessel disease. Circulation 1986;73:710-717

10. Faxon DP, Detre KM, McGabe $\mathrm{CH}$. Fisher $\mathrm{L}$, Holmes DR. Cowley J, Bourassa M, van Raden M, Ryan TJ. Role of percutaneous transluminal coronary angioplasty in the treatment of unstable angina: report from the National Hearl. Bloced and Lung Institule. Am I Cardiol 1983:53:131C-135C.

11. Luyten HE, Beatt KJ, de Feyter PJ, van den Brand M, Reiher JHC. Strruys PW. Angioplasty for stable versus unstable angina pectoris: are unstable patients more likely to get restenosis? Int I Card Imaging 1988:3:87-97.

12. Safian RD, Gelbfish JS. Emy RE. Schnitt SJ, Schmidt D. Biam DS. Coronitry atherectomy: clinical, angiographic and histologic findings and observations regarding potential mechanisms. Circulation 1990:82:69-79.

13. Hinohara T, Rowe M, Robertson GC, Selmon MR. Braden L., I egget JH, Velter JW. Simpson JB. Effect of lesion characteristics on outcone of dircciconal coronary atherectomy. I Am Coll Cardiol 1991:17:1112-1120.

14. Garrat KN, Holmes DR, Bell MR, Bresnahan JF, Kaufmann LP, Vlictstra RE. Edwards WD. Restenosis after directional coronary atherectomy: differences between primary atheromatous and restenosis lesions and intluence of subintimal tissue resection. $J$ Am Coll Cardiol 1990;16:1665 1671.

15. Sernus PW. Umans VA. Strauss $B H$, van Suylen RJ, van den Brand $M$. Suryapranata H. de Feyter PJ. Quantitative angiography after directional coronary atherectomy. Br Hort $/ 1091 ; 66: 122-129$

16. Umans VAWM, Strauss BH. Rensing BJWM, de Jaegere P. de Feyter PJ, Serruys $\mathrm{PW}$. Comparative angiographic quantitative analysis of the immediate efficacy of coronary atherectomy with balloon angioplasty. stenting and rotatiomal ablation. Am Heart I 1991:122:836-843

17. L mans VA. Beatt KJ, Rensing B, Hermans W, de Feyer PJ, Serruys PW. Comparative quantitative angiographic analysis of directional coronary atherectomy and balloon coronary angioplasty. Am / Cardiol 1991:68:1556-1563.

18. Reiber JHC, Seruys PW. Quantitative coronary angiography. In Marcus MI. Schelbert HR, Skorton DJ, and Wolf GL. eds. Cardiac lmaging: A Companion to Braunwald's Heart Disease. Philadelphia: WB Saunders, 1991:213-280.

19. Reiber JHC, Serruys PW, Kooyman CJ, Wijns W, Sliger CI. Cierbrands JJ, Schuurbiers JCH. den Boer A. Hugenholtz PG. Assessment of short-, medium- and long-term variations in arterial dimensions from computer atsisisted quatntitation of coronary cineangiograms. Circulation 1985:71:280-288.

20. Umans VAWM, Robert A, Foley D. Haine E. de Feyter PJ, Wigns W. Sertuys PW. Restenosis after directional coronary atherectomy: a multivariate analysin of late outcome and renarrowing process. I Am Coll Cordin! 1994:23:44-59. 
21. Rensing BJ, Hermans WRM, Vos J, Tijssen JGP, Rutsch W, Danchin N, Heyndrickx GR, Mast EG, Wijns W, Serruys PW. Luminal renarrowing after percutaneous transluminal coronary angioplasty: a study of clinical, procedural and lesional factors related to long-term angiographic outcome. Circulation 1993;88:975-985. 22. Hermans WRM, Rensing BJ, Foley DP, Tijssen JGP, Rutsch W, Emanuelsson H, Danchin N, Wijns W, Chappuis F, Serruys PW. Patient, lesion and procedural variables as risk faccors for luminal renarrowing after successful coronary angioplasty: a quantitative analysis in 653 patients with 778 lesions. J Cardiovasc Pharmacol 1993;22(suppl 4):S45-S57.

23. de Feyter PJ, van den Brand M, Laarman GJ, van Domburg R, Serruys PW, Suryapranata $\mathrm{H}$. Acute coronary occlusion during and after percutaneous transluminal coronary angioplasty: frequency, prediction, clinical course, management and follow up. Circulation 1991:83:927-936.

24. Popma JJ, Topol EJ, Hinohara T. Abrupt closure after directional coronary atherectomy: clinical, angiographic and procedural outcome. Circulation 1992;19. $1372-1379$.

25. Ellis SG, DeCesare NB, Pinkerton CA. Relation of stenosis morphology and clinical presentation to the procedural results of directional coronary atherectomy. Circulation 1991;84:644-653.

26. Ambrose JA, Winters SL, Tern A. Angiographic morphology and the pathogenese of unstable angina. $J$ Am Coll Cardiol 1985;5;609-616.

27. Gorlin R, Fuster V, Ambrose JA. Anatomic-pathologic link between acute coro- nary syndromes. Circulation 1986;74:6-9.

28. Sherman CT, Litvack F, Grundvest W, Lee M, Hickey A, Chaux A, Kass R, Blanche C, Mathoff J, Morgenstem L, Janz W, Swan HJC, Forrester J. Coronary angioscopy in patients with unstable angina pectoris. $N$ Engl J Med 1986;315: 912-919.

29. Escaned J, van Suylen RJ, MacLeod DC, Umans VAWM, de Jong M, Bosman FT, de Feyter PJ, Serruys PW. Histologic characteristics of tissue excised during directional coronary atherectomy in patients with stable and unstable angina pectoris. Am J Cardiol 1993;71:1442-1446.

30. Ramee SR, White CJ, Collins TJ, Mesa JE, Murgo JP. Percutaneous angioscopy during coronary angioplasty using a steerable microangioscope. $J \mathrm{Am} \mathrm{Coll} \mathrm{Cardiol}$ 1991;17:100-105.

31. Fishman RF, Kuntz RE, Carrozza JP, Miller MJ, Senerchia CC, Schnitt SJ, Diver DJ, Safian RD, Baim DS. Long-term results of directional coronary atherectomy: predictors of restenosis. J Am Coll Cardiol 1992;20:1101-1110.

32. Foley JB, Chisholm RJ, Common AA, Langer A, Armstrong PW. Aggressive clinical pattem of angina at restenosis following coronary angioplasty in unstable angina. Am Heart J 1992; 124:1174-1180.

33. Kamp O, Beatt KJ, de Feyter PJ, van den Brand M, Suryapranata H, Luyten HE, Serruys PW. Short-, medium- and long-term follow-up atter percutaneous transluminal coronary angioplasty for stable and unstable angina pectoris. Am Heart I 1989;117:991-996. 